\title{
The $\mathrm{X}$ chromosome and male infertility
}

\author{
Matthias Vockel ${ }^{1} \cdot$ Antoni Riera-Escamilla $^{2} \cdot$ Frank Tüttelmann $^{1}$ (1) $\cdot$ Csilla Krausz $^{2,3}$ (])
}

Received: 24 November 2019 / Accepted: 10 December 2019 / Published online: 24 December 2019

(c) The Author(s) 2019

\begin{abstract}
The X chromosome is a key player in germ cell development, as has been highlighted for males in previous studies revealing that the mammalian $\mathrm{X}$ chromosome is enriched in genes expressed in early spermatogenesis. In this review, we focus on the $\mathrm{X}$ chromosome's unique biology as associated with human male infertility. Male infertility is most commonly caused by spermatogenic defects to which X chromosome dosage is closely linked; for example, any supernumerary X chromosome as in Klinefelter syndrome will lead to male infertility. Furthermore, because males normally only have a single X chromosome and because X-linked genetic anomalies are generally only present in a single copy in males, any loss-of-function mutations in single-copy X-chromosomal genes cannot be compensated by a normal allele. These features make X-linked genes particularly attractive for studying male spermatogenic failure. However, to date, only very few genetic causes have been identified as being definitively responsible for male infertility in humans. Although genetic studies of germ cell-enriched $\mathrm{X}$-chromosomal genes in mice suggest a role of certain human orthologs in infertile men, these genes in mice and humans have striking evolutionary differences. Furthermore, the complexity and highly repetitive structure of the X chromosome hinder the mutational analysis of $\mathrm{X}$-linked genes in humans. Therefore, we conclude that additional methodological approaches are urgently warranted to advance our understanding of the genetics of X-linked male infertility.
\end{abstract}

\section{Introduction}

Infertility is a frequent condition affecting one out of six couples in Western countries (Krausz and Riera-Escamilla 2018). Male factors contribute to infertility in about $50 \%$ of cases and can be classified into four major etiological categories: (i) hypothalamic-pituitary axis dysfunction; (ii)

Matthias Vockel and Antoni Riera-Escamilla are co-first authors.

Frank Tüttelmann and Csilla Krausz are co-last authors.

Frank Tüttelmann

frank.tuettelmann@ukmuenster.de

Csilla Krausz

csilla.krausz@unifit.it

1 Institute of Human Genetics, University of Münster, Vesaliusweg 12-14, 48149 Münster, Germany

2 Andrology Department, Fundació Puigvert, Universitat Autònoma de Barcelona, Instituto de Investigaciones Biomédicas Sant Pau (IIB- Sant Pau), Barcelona, Catalonia, Spain

3 Department of Experimental and Clinical Biomedical Sciences "Mario Serio", Centre of Excellence DeNothe, University of Florence, Viale PIeraccini, 6, 50139 Florence, Italy quantitative alterations of spermatogenesis; (iii) qualitative alterations of spermatogenesis; and (iv) ductal obstruction/ dysfunction (Tournaye et al. 2016). Known genetic factors are present in each of these etiological categories, and, depending on the severity of the spermatogenic impairment, they account for about $10-20 \%$ of cases. With the advent of large-scale sequencing strategies (especially exome analysis by next-generation sequencing, or NGS), more and more novel genes have been reported to be linked with male infertility. However, the majority of these genes still lack a definitive gene-disease relationship (Oud et al. 2019). Further, about $40 \%$ of quantitative spermatogenic impairment cases cannot be causally diagnosed and are instead referred to as unexplained or idiopathic infertility; a large proportion of these cases are likely caused by yet unknown genetic factors.

Both sex chromosomes in males ( $\mathrm{X}$ and $\mathrm{Y}$ ) are enriched in genes specifically or overexpressed in the testis (Skaletsky et al. 2003; Mueller et al. 2008). Moreover, in males, de novo or rare mutations in these chromosomes may have a direct phenotypic effect because there is no second compensatory X or Y allele. The role of Y chromosome-linked deletions in male infertility has been well understood since 1996 (Vogt et al. 1996). Here, the removal of genes belonging to the so-called azoospermia factor (AZF) region causes 
azoospermia or oligozoospermia (Krausz et al. 2014; Krausz and Casamonti 2017). While screening for Y chromosome deletions is a fundamental part of the diagnostic workup of severe oligo/azoospermic men, only two X chromosomelinked genes are routinely tested in selected pathological conditions (ANOS1 and AR). Thanks to high-throughput approaches such as whole exome sequencing (WES) and comparative genomic hybridization (CGH) arrays, novel $\mathrm{X}$-linked gene mutations (e.g., TEX11 and ADGRG2) have been discovered as causative factors of different infertile phenotypes.

In light of these findings, in this review we will discuss (i) $\mathrm{X}$-linked genes and male fitness from an evolutionary point of view; (ii) the clinical consequences of X-linked aneuploidies and deletions; (iii) the role of X-linked gene mutations in male infertility.

\section{Structure and function of the $\mathrm{X}$ chromosome}

While both sex chromosomes are derived from a pair of autosomes around 300 million years ago, most ancestral functional elements have been only conserved on the $\mathrm{X}$ chromosome (Ross et al. 2005). The sex chromosome's size also differs dramatically, and while the $\mathrm{X}$ chromosome has remained relatively stable in magnitude with around $155 \mathrm{Mb}$, the $\mathrm{Y}$ chromosome decreased to around $55 \mathrm{Mb}$. The $\mathrm{X}$ chromosome contains about 800 (human) to 850 (murine) protein-coding genes (Mueller et al. 2013), for which a disproportionately high number of inherited diseases were documented. The unique gene composition of the $\mathrm{X}$ chromosome also allows balanced gene dosage compensation through a well-regulated spatial and temporal expression of $\mathrm{X}$-linked genes (Deng et al. 2014).

The $\mathrm{X}$ chromosome was previously considered the most stable chromosome of the genome (Ohno 1967) and was largely perceived as a "female" counterpart to the "male" $\mathrm{Y}$ chromosome. But, to the contrary, it turns out that the $\mathrm{X}$ chromosome is in a current state of rapid evolution toward a specialized role for sperm production.

The hemizygosity in males allows for unique evolutionary patterns of X-linked genes for male sexual fitness and can favor positive selection of advantageous variants (Vicoso and Charlesworth 2006). Accordingly, the $X$ chromosome is enriched for sex-biased (Khil et al. 2004) and spermatogonia-expressed (Wang et al. 2001) genes. However, X-linked genes are thought to be silenced during male meiosis by a mechanism known as meiotic sex chromosome inactivation (Turner 2007). To compensate for this inactivation, large gene families with multiple copies have accumulated on the X chromosome (Warburton et al. 2004), and these homologous palindromic repeats are highly expressed in spermatids (Mueller et al. 2008). An example of an X-chromosomal multigene family is the large superfamily called cancer testis antigens (CTA), in which members are arranged into complex direct and palindromic repeats. As has been estimated, CTA families account for around 10\% of X-linked genes (Simpson et al. 2005; Almeida et al. 2009), and they can be divided into the MAGE multigene family and the NY-ESO- 1 family in region Xq24-q28 and the $S S X$ family and GAGE/ $P A G E / X A G E$ families in region Xp11 (Zendman et al. 2003). Most of the CTA genes are expressed during spermatogenesis, but their function in both germline tissues and tumors remains poorly understood (Fratta et al. 2011).

It has been speculated that multicopy regions on the $\mathrm{X}$ chromosome may have an important function for germ cell survival, e.g., through dosage compensation. In this regard, homologous repeats could self-pair during male meiosis such that they would potentially be protected from unpaired chromosome inactivation, as has been suggested for the Y chromosome (Skaletsky et al. 2003). However, a recent study implies that copy number expansions of palindromic genes might not be essential for spermatogenesis, as reduced ampliconic gene expression following deletion of large $\mathrm{X}$-linked palindromes did not reduce fertility in male mice (Kruger et al. 2018).

\section{$X$ chromosome-linked genes and male fitness: an evolutionary perspective}

More than 50 years ago, it was postulated that the $\mathrm{X}$ chromosome is in an evolutionary stable state, and X-linked genes should differ little between placental mammals (Ohno 1967). This hypothesis, called 'Ohno's law', is supported by several comparative mammalian studies (e.g., Murphy et al. 1999; Kuroiwa et al. 2001; Raudsepp et al. 2004; Ross et al. 2005). Later though, it was shown that $\mathrm{X}$ chromosomes have undergone rapid evolutionary changes, and accumulation of ampliconic genes has occurred individually during mammalian evolution (Bellott et al. 2010; Mueller et al. 2013). This comparison of multicopy genes in different lineages has offered important insights into the mammalian evolution of X-linked genes. While most of the single-copy genes on the mouse and human $\mathrm{X}$ chromosomes are conserved between these species, approximately 340 genes are not shared between the two species, and most of these unshared genes are found in ampliconic regions (Fig. 1). About 10\% of the human and $16 \%$ of mouse X-linked genes, respectively, have been independently acquired since their divergence from a common ancestor. In contrast to the shared, singlecopy genes, these ampliconic genes are notable exceptions to the postulated Ohno's law. Expression analyses further revealed that these ampliconic genes are active almost exclusively in testicular germ cells, but not in 


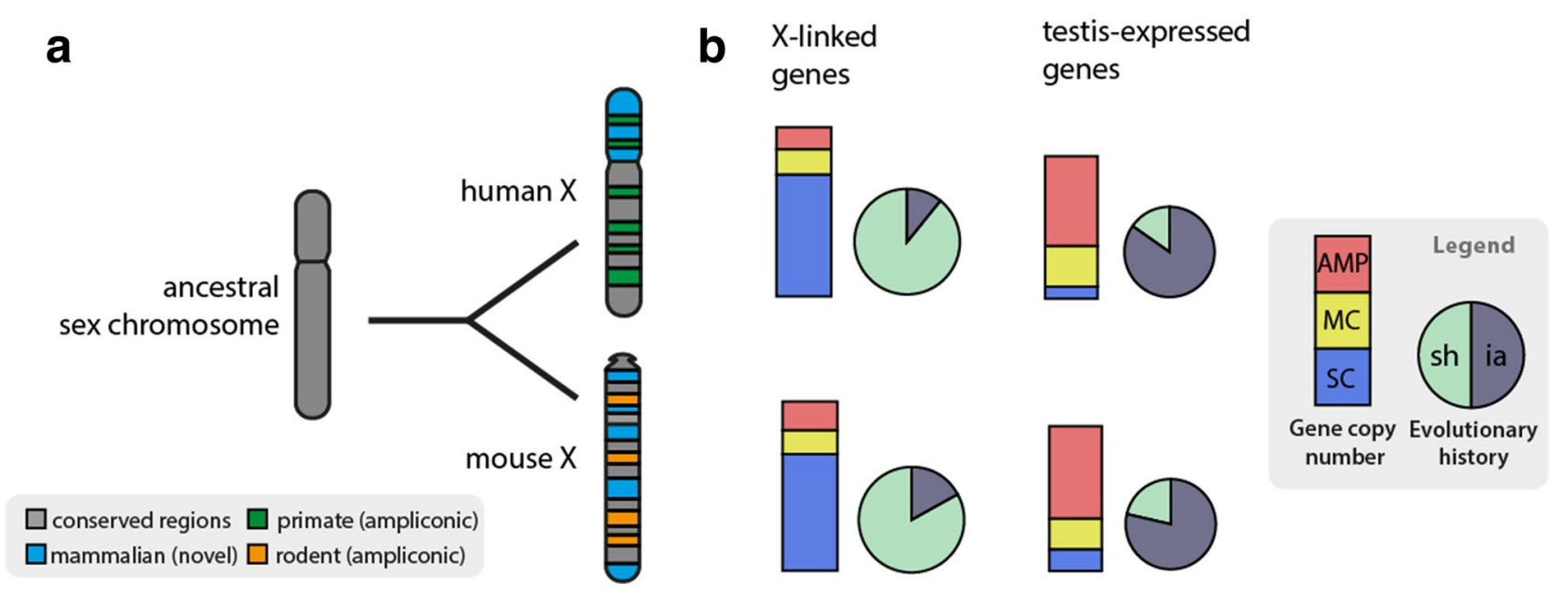

Fig. 1 Evolution of mammalian $\mathrm{X}$ chromosomes. Contrary to Ohno's law, the gene content of the $\mathrm{X}$ chromosomes differs significantly within the mammalian lineage. a Schematics of the variability of X-linked genes between rodents and primates. Colors denote the divergent evolutionary origins of X-linked genes. Gray: conserved ancestral regions (corresponds to the long arm of the human $\mathrm{X}$, and this region is rearranged in mice); Blue: acquired gene content in mammals (short arm of human $\mathrm{X}$, region rearranged in mice); green and orange: independently acquired ampliconic genes in humans and mice, respectively (positions correspond to arbitrary genomic locations). b Depicted diagrams show a comparison of all X-linked

other male tissues or female tissues. As such, they are likely to contribute to sperm production (Mueller et al. 2013). Although the physiological functions of most independently acquired, ampliconic genes are still unclear, their rapid evolution suggests a strong positive selection that may have contributed to speciation.

It is possible that these genes have significant roles in diseases related to infertility, but the use of model systems for these genes is complicated because they are not conserved in mice. This caveat seems to apply to all sexlinked genes, as a recent study has suggested that sex bias in overall gene expression also arose recently in mammalian evolution and, hence, could be species specific, which might prevent results on molecular variation from being translated from animal models to human reproduction research (Naqvi et al. 2019). Furthermore, sex chromosomes evolve functional specialization by accumulation of sexually antagonistic as well as sex-biased genes (Vicoso and Charlesworth 2006; Parsch and Ellegren 2013). The significant enrichment for testis-expressed genes on the $\mathrm{X}$ chromosome and the differential expression of sex-biased genes imply that sexual conflict has profound consequences on gene content evolution of $\mathrm{X}$ chromosomes in mammals (Gurbich and Bachtrog 2008; Larson et al. 2018).
( $n=800$ human, 853 mouse) and predominantly testis-expressed genes (expression patterns of eight human tissues and three mouse tissues) in humans and mice. Bar graphs: percentages of protein-coding X-linked genes categorized as single copy (SC, blue), multicopy (MC, yellow) or ampliconic (AMP, red). Pie charts: percentages of $\mathrm{X}$-linked genes that are shared (sh, light green) in both species or are independently acquired (ia, dark blue) after the divergence of humans and mice. Most ampliconic X-linked genes have been independently acquired in primates and rodents and are predominantly expressed in testes (data adopted from Bellott et al. 2010; Mueller et al. 2013; Deng et al. 2014)

\section{The consequences of too much and too little $X$ chromosome}

\section{Too much X: Klinefelter syndrome}

Klinefelter syndrome (KS) is a chromosomal condition that was first described in 1942 (Klinefelter et al. 1942). It was not until 1959 when Jacobs and Strong (1959) determined that it was caused by the presence of an extra $\mathrm{X}$ chromosome. Various genotypes are associated with this condition, the most common being 47, XXY in up to $80-90 \%$ of cases, while in approximately $10 \%$ of cases the genotype is a mosaic form of $47, \mathrm{XXY} / 46, \mathrm{XY}$. Other rare variants are 48,XXXY; 48,XXYY; 49,XXXXY; 49,XXXYY; and 49,XXYYY and are associated with more severe phenotypes (Visootsak et al. 2001; Tartaglia et al. 2008; Ottesen et al. 2010). KS shows an estimated frequency of 1:600 in the general population, whereas in patients with non-obstructive azoospermia it is as high as $15 \%$. In adults, the diagnosis is mainly made because of infertility and/or sexual dysfunction. The reproductive phenotype of these individuals includes small, firm testes with hyalinization of seminiferous tubules with consequent spermatogenic failure. In fact, over $90 \%$ of KS patients are 
azoospermic, and the remaining show crypto/severe oligozoospermia. Despite that spontaneous puberty is observed in these patients; the majority of them present signs of androgen deficiency, which range from hypogonadism with gynecomastia and eunuchoid proportions to variable levels of undervirilization.

Natural pregnancies have been reported mostly in mosaic KS cases. For the majority of non-mosaic 47,XXY KS men, conception of a biological child is only possible through testicular sperm extraction (TESE), either conventional TESE or microTESE combined with intracytoplasmic sperm injection (ICSI) (Corona et al. 2017). The success rate of sperm retrieval varies in different laboratories, but according to a recent meta-analysis the mean sperm retrieval rate (SRR) is about 44\% (Corona et al. 2017). Although an accurate prediction of SRR is not possible, age seems to be a relevant prognostic parameter, and KS patients under 30 years old show a higher success rate (Rohayem et al. 2015). Hence, an early diagnosis of this syndrome is clearly relevant, since it would allow both the preservation of fertility and the introduction of preventive therapies to avoid or to better control associated co-morbidities. In fact, besides reproductive/sexual problems, KS patients may present a series of co-morbidities such as metabolic syndrome, autoimmune diseases, osteoporosis, breast and germ cell tumors, venous thromboembolisms and cognitive/psychiatric disturbances (Gravholt et al. 2018 and references therein).

What underlies the heterogeneous phenotypic presentation is still not clear, but is probably related to various factors (Tüttelmann and Gromoll 2010; Zitzmann et al. 2015). For instance, the proposed phenotypic modulators include parental origin of the extra $\mathrm{X}$ chromosome, the androgen receptor CAG repeat length, gene dosage dysregulation, and/or epigenetic events. First, the parental origin of the supernumerary $\mathrm{X}$ chromosome has only been addressed by few studies reporting a potential effect on impaired speech/ motor development (Stemkens et al. 2006), later onset of puberty (Wikstrom et al. 2006) and schizotypal traits (Bruining et al. 2010). While impaired speech/motor developmental problems and later onset of puberty were significantly associated with paternal origin of the $\mathrm{X}$ chromosome, significantly higher scores on schizotypal traits were associated with maternal origin.

Next, regarding the CAG repeats in the androgen receptor $(A R)$ gene, the number modulates its transcriptional activity in vitro (Gao et al. 1996), and an increased number of repeats was positively correlated with height, arm span and both arm and leg length in KS patients (Zitzmann et al. 2004; Bojesen et al. 2011; Chang et al. 2015). On the other hand, data on the (CAG)n polymorphism in relation to testicular volume, gynecomastia, lipid metabolism and bone-related parameters are still controversial (Gravholt et al. 2018 and references therein).
Regarding dosage dysregulation, women have two $\mathrm{X}$ chromosomes, while men only have one. Thus, to compensate for the difference in gene dosage, in females one of the two $\mathrm{X}$ chromosomes is inactivated. However, a small portion of X-chromosomal genes ( 10-15\%) escape inactivation, among it the PAR genes. In this regard, the overdosage of SHOX has been demonstrated to be associated with the typical excess height of KS patients. Apart from SHOX, other PAR genes such as $C D 99$ and $C S F 2 R A$ were found differentially expressed in the KS group vs. male controls (Zitzmann et al. 2015). The overexpression of these two genes could contribute to the development of some of the typical comorbidities of KS [overexpression of $C D 99$ was associated with inflammatory cytokines, whereas $C S F 2 R A$ with insulin resistance, waist circumference, and concentrations of the procoagulatory substance PAI-1 and cytokines (Zitzmann et al. 2015)].

Finally, regarding epigenetic events, the supernumerary X chromosome in KS has an interesting effect on DNA methylation. Methylome studies in blood and brain samples have shown differences between KS patients and 46,XY males (Viana et al. 2014; Sharma et al. 2015; Wan et al. 2015; Skakkebaek et al. 2018). Unfortunately, only few overlapping differentially methylated regions (DMRs) have been observed between studies, which could be in part explained by differences in the type of sample analyzed (blood vs brain) and the resolution of the arrays (Illumina $27 \mathrm{~K}$ vs Illumina450K) (Skakkebaek et al. 2018 and references therein). Gene set enrichment analysis of the observed DMRs showed an overrepresentation of terms relevant to the KS phenotype such as diabetes, obesity, height, coronary and arterial disease, hypercholesterolemia, gingivitis and periodontitis, bone mineral density, cancer (breast, prostate, colon, pancreas, leukemia, lymphoma), connective tissue diseases, infection and inflammation and others (Skakkebaek et al. 2018). However, it is still unknown whether these epigenetic alterations are responsible for the KS co-morbidities through altering gene expression regulation. In fact, only a moderate correlation between epigenetic alterations and some of the phenotype-associated gene expression levels (BOLAl, DDX43, ZBTB44 and KDM5C) has been observed (Skakkebaek et al. 2018). Further studies on different tissue samples are needed to elucidate the biological basis for the heterogeneous phenotypic presentation of KS.

\section{Too little X: X-linked deletions}

Copy number variants (CNVs) are a type of structural variant involving alterations in the number of copies of specific regions of DNA (often defined as above $1 \mathrm{~kb}$ in length) in comparison with a reference genome (Feuk et al. 2006). The functional consequence of a CNV can be difficult to predict and depends on the exact position of the CNV breakpoint, 
i.e., the region where a fragment was inserted (gain/duplication) or lost (loss/deletion). CNVs may affect gene function directly or indirectly. A direct effect through the involvement of coding sequences may be the consequence of the CNV (i) altering the copy number of dosage-sensitive genes; (ii) disrupting the gene-coding sequence, as partial gain or deletion of coding sequences can produce different alleles, including both loss and gain of function; or (iii) producing chimeric proteins when CNV breakpoints lie within two different genes, leading to the fusion of two partial coding regions. An indirect effect may occur when CNVs lie in noncoding regions and disrupt the function of genes through the deletion or transposition of critical regulatory elements, such as promoters, enhancers and silencers (Hurles et al. 2008).

A number of CNVs generate alleles with a pathogenic effect in andrology; the best examples of such a clear-cut effect are the Y-chromosomal AZF deletions (Krausz et al. 2014; Krausz and Casamonti 2017). Comparative genomic hybridization $(\mathrm{CGH})$ arrays (whole genome or X chromosome specific) have been employed to analyze patients with quantitative spermatogenic disturbances in five laboratories (Tüttelmann et al. 2011; Krausz et al. 2012; Stouffs et al. 2012; Lopes et al. 2013; Yatsenko et al. 2015), and four of them provide information about X-linked CNVs (Tüttelmann et al. 2011; Krausz et al. 2012; Lopes et al. 2013; Yatsenko et al. 2015). Comparing the raw data of these studies, only few partially overlapping CNVs have been observed, which could be in part explained by differences in the resolution of the arrays (Krausz et al. 2015). The only consistent finding of the available studies is that there is a significantly higher 'burden' of deletions, particularly on the X chromosome, in infertile men versus normozoospermic controls. The observed higher burden of X-linked deletions has been hypothesized to be an expression of a generalized genomic instability, which may also lead to general health problems. This hypothesis would be in line with the epidemiological observations showing a link between altered spermatogenic function and a higher incidence of morbidity (including cancer) and lower life expectancy (Jensen et al. 2009; Salonia et al. 2009; Eisenberg et al. 2014).

Besides the CNV burden, CGH arrays have allowed researchers to identify a few X-linked deletions with a possible role in male infertility (Krausz et al. 2015 and references therein). Only one potential clinically relevant $\mathrm{X}$ chromosome-linked deletion has been analyzed in several studies. CNV67 was first described as patient specific in $1.1 \%$ (7/627) of infertile men from Spain and Italy (Lo Giacco et al. 2014). A subsequent study in a Mediterranean population confirmed the role of the CNV67 in male infertility, since it was found in $1.2 \%$ of infertile men but not in normozoospermic controls (Pinho et al. 2019). The CNV67 has also been analyzed in the Chinese population with controversial results. One study reported that $6 / 884$ infertile patients carried the deletion, whereas it was not found in any of the 838 controls from Sichuan Province in southwestern China (Shen et al. 2017). On the contrary, Ma et al. (2017) reported the prevalence of the CNV67 to be about $3 \%$ in fertile controls, but the controls had unknown sperm counts and belonged to a specific geographic area (the Guandong population). The exact mechanism by which CNV67 may alter spermatogenesis is still unknown. Studies have suggested that the CNV67 might cause a partial deletion of the proximal copy of the MAGEA9B gene, which is a CTA specifically expressed in the testis and in some tumors (Shen et al. 2017). In summary, further studies in multiple populations including fertile controls with known sperm counts are needed to elucidate the clinical relevance of this CNV.

\section{$X$ chromosome-linked gene mutations in male infertility}

Many X-linked genes are promising candidates as causes for infertility owing to their testicular expression and expected involvement in spermatogenesis. The advances in highthroughput sequencing approaches have allowed for the identification of additional genetic factors in azoospermic patients either by targeted sequencing or exome sequencing. However, most studies have not been replicated so far, and the functional roles of most genes are still ill-defined. Furthermore, the repetitive nature of the $\mathrm{X}$ chromosome can complicate the detection of deleterious variants. Although several candidate genes have been postulated, the number of promising or definitively causative genes for male infertility remains low when assessed in a standardized way (Smith et al. 2017), as has recently been done by Oud and collogues (Oud et al. 2019); see Table 1.

\section{Non-obstructive azoospermia (NOA)}

\section{AR}

The androgen receptor $(A R)$ remains the best studied $\mathrm{X}$-linked gene so far in the etiology of male infertility. The AR is critical for diverse developmental processes and generally functions as a DNA-binding transcription factor. Upon binding of steroid hormone ligands in the cytoplasm, the receptor translocates into the nucleus and then stimulates the expression of androgen-responsive genes. The phenotype of patients with mutations in AR is highly variable and varies from complete androgen insensitivity syndrome (CAIS) with sex reversal to mild symptoms (Brinkmann 2001). Patients with mild androgen insensitivity syndrome (MAIS) in particular can have normal genitalia and isolated male infertility. Variants detected in infertile patients are mainly 
Table 1 Overview of disease-associated X-linked genes with testis-specific expression in mice and humans

\begin{tabular}{|c|c|c|c|c|c|}
\hline Gene & $\begin{array}{l}\text { Semen/testicular pheno- } \\
\text { type }\end{array}$ & Proposed functions & Mouse phenotype & Publications & Level of evidence \\
\hline \multicolumn{6}{|c|}{ Phenotype: isolated spermatogenic failure } \\
\hline$A R$ & $\begin{array}{l}\text { Oligozoospermia, azoo- } \\
\text { spermia }\end{array}$ & $\begin{array}{l}\text { Hormone activated tran- } \\
\text { scription factor }\end{array}$ & $\begin{array}{l}\text { Infertile; partial androgen } \\
\text { insensitivity syndrome }\end{array}$ & $\begin{array}{l}\text { Hiort et al. (2000), Ferlin } \\
\text { et al. (2006) }\end{array}$ & Definitive \\
\hline TEX11 & $\begin{array}{l}\text { Non-obstructive azoo- } \\
\text { spermia, meiotic arrest }\end{array}$ & $\begin{array}{l}\text { Meiotic DNA recombina- } \\
\text { tion }\end{array}$ & Infertile; meiotic arrest & $\begin{array}{l}\text { Yang et al. (2015a), Yat- } \\
\text { senko et al. (2015) }\end{array}$ & Strong \\
\hline$M A G E B 4$ & $\begin{array}{l}\text { Non-obstructive azoo- } \\
\text { spermia }\end{array}$ & Germ cell-specific mitosis & No mouse model & Okutman et al. (2017) & Limited \\
\hline HAUS7 & Severe oligozoospermia & $\begin{array}{l}\text { Meiotic chromosome } \\
\text { alignment }\end{array}$ & No mouse model & Li et al. (2018) & Limited \\
\hline USP26 & $\begin{array}{l}\text { Oligozoospermia, azoo- } \\
\text { spermia }\end{array}$ & $\begin{array}{l}\text { Deubiquitinating pepti- } \\
\text { dase }\end{array}$ & Fertile & Paduch et al. (2005) & Limited \\
\hline RHOXF $1 / 2$ & Oligozoospermia, severe & $\begin{array}{l}\text { Homeodomain transcrip- } \\
\text { tion factor }\end{array}$ & No mouse model & Borgmann et al. (2016) & No evidence \\
\hline$T A F 7 L$ & $\begin{array}{l}\text { Non-obstructive azoo- } \\
\text { spermia }\end{array}$ & TFIID transcription factor & $\begin{array}{l}\text { Complete spermatogen- } \\
\text { esis; abnormal sperm } \\
\text { number/morphology }\end{array}$ & Akinloye et al. (2007) & No evidence \\
\hline \multicolumn{6}{|c|}{ Phenotype: obstructive azoospermia/CBAVD } \\
\hline$A D G R G 2$ & $\begin{array}{l}\text { Congenital bilateral } \\
\text { absence of the vas defer- } \\
\text { ens (CBAVD) }\end{array}$ & $\begin{array}{l}\text { G-protein-dependent fluid } \\
\text { homeostasis }\end{array}$ & Infertile; obstructive & Patat et al. (2016) & Strong \\
\hline CLDN2 & Obstructive azoospermia & $\begin{array}{l}\text { BTB tight junction forma- } \\
\text { tion }\end{array}$ & Fertile & Askari et al. (2019) & Limited $^{\mathrm{a}}$ \\
\hline \multicolumn{6}{|c|}{ Phenotype: astheno-/teratozoospermia } \\
\hline PIH1D3 & Asthenozoospermia & Flagella dynein assembly & Infertile; mild PCD & $\begin{array}{l}\text { Paff et al. (2017), Olcese } \\
\text { et al. (2017) }\end{array}$ & Strong \\
\hline$A K A P 4$ & $\begin{array}{l}\text { Asthenozoospermia, } \\
\text { teratozoospermia }\end{array}$ & $\begin{array}{l}\text { PKA binding in sperm } \\
\text { flagellum }\end{array}$ & $\begin{array}{l}\text { Infertile; multiple } \\
\text { morphological abnor- } \\
\text { malities of the sperm } \\
\text { flagella }\end{array}$ & $\begin{array}{l}\text { Baccetti et al. (2005), } \\
\text { Visser et al. (2011) }\end{array}$ & Limited \\
\hline FATE1 & Oligoasthenozoospermia & $\begin{array}{l}\text { SF1-dependent mitochon- } \\
\text { drial regulation }\end{array}$ & No mouse model & Olesen et al. (2003) & No evidence \\
\hline \multicolumn{6}{|c|}{ Phenotype: Kallmann syndrome } \\
\hline ANOS1 & $\begin{array}{l}\text { Oligozoospermia, azoo- } \\
\text { spermia }\end{array}$ & GnRH neuronal migration & $\begin{array}{l}\text { Infertile; hypogonado- } \\
\text { tropic hypogonadism }\end{array}$ & Gonçalves et al. (2017) & Definitive \\
\hline
\end{tabular}

${ }^{a}$ Not in Oud et al. (2019) because published subsequently. Assessment according to same criteria by MV and FT independently

missense mutations affecting the transactivation potential of the AR (Goglia et al. 2011; O'Hara and Smith 2015). However, of the great number of reported AR mutations (Gottlieb et al. 2012), only a small number have been clearly associated with azoospermia or oligozoospermia. Thus, $A R$ mutations can be considered a rare cause of male infertility (Hiort et al. 2000; Ferlin et al. 2006).

Furthermore, the $A R$ gene contains a polymorphic CAG repeat in exon 1. Repeats longer than 35 are associated with spinal and bulbar muscular atrophy (SBMA) and prostate cancer (McCrea et al. 2016; Cortes and La Spada 2018). Besides, the length of the polymorphic CAG repeat encoding a polyglutamine stretch (8-35 in length) in the AR N-terminal transactivation domain has been linked to male infertility. The number of CAG repeats is inversely correlated with transcriptional activity in vitro (Tut et al. 1997; Ferlin et al. 2004). The association between the AR-CAG repeat and male infertility has been intensively studied, but effects seem to be small and are still debated. Longer CAG repeat lengths may be a risk factor for male infertility, although population studies with variation detection in healthy controls argue against a strong association with unexplained male infertility, as concluded from large meta-analyses (Davis-Dao et al. 2007; Xiao et al. 2016). The transactivation domain of the AR comprises a further polyglycine tract (10-30 in length) encoded by a repeat consisting of GGN trinucleotides. However, the functional effect of the polyglycine tract remains controversial (Jääskeläinen 2012; Grigorova et al. 2017).

Apart from $A R$, additional $\mathrm{X}$-chromosomal genes have been postulated to be causative for male infertility, including TEX11, MAGEB4, RHOX and TAF7L. 


\section{TEX11}

TEX11 encodes a protein that regulates DNA recombination and formation of chromosome synapses and crossovers (Adelman and Petrini 2008). The gene is highly expressed in late spermatocytes and in spermatids in mice (Wang et al. 2001), and disruption of Texl1 in knock-out mice causes meiotic arrest and results in azoospermia (Yang et al. 2008). Recently, an intragenic TEX11 deletion removing exons 10-12 was identified by high-resolution X-specific arrayCGH in two infertile patients with NOA due to meiotic arrest and mixed testicular atrophy, respectively (Yatsenko et al. 2015). Further analysis by targeted sequencing identified further TEX11 variants of which loss-of-function (LoF) mutations were associated with meiotic arrest, while the role of missense variants remains less clear (Yatsenko et al. 2015; Yang et al. 2015a). Together, these data provide strong evidence that LoF variants in TEX11 cause non-obstructive azoospermia due to meiotic arrest also in human males.

\section{MAGEB4}

MAGEB4 is a type I melanoma antigen gene from the CTA family specifically expressed during germ cell differentiation with a yet-unclear function, although a role in murine germ cell-specific mitosis has been postulated (Osterlund et al. 2000). This gene is part of a multicopy gene cluster of type I melanoma antigens (Lee and Potts 2017). In a single consanguineous family, a stop-loss variant was segregated with azoospermia and oligozoospermia (Okutman et al. 2017). The evidence that this gene plays a causative role in NOA is currently very limited, as (i) the functional relevance of the described stop-loss variant is still unclear; (ii) no other variants in MAGEB4 have been identified so far; and iii) the role of other homologous MAGE family members remains elusive.

\section{HAUS7}

HAUS7 encodes a subunit of the human Augmin protein complex (Goshima et al. 2008) with a proposed function in chromosome alignment during meiosis. While a single HAUS7 variant has been described in a familial case of severe oligozoospermia ( $\mathrm{Li}$ et al. 2018), its role in NOA pathology remains to be determined.

\section{USP26}

USP26 is a deubiquitylating enzyme with a transcription pattern restricted to the male germline (Wang et al. 2001). Several variants of unknown clinical significance were reported in azoospermic patients (Paduch et al. 2005; Ma et al. 2016; Luddi et al. 2016). However, reported missense and nonsense USP26 variants were also detected in fertile controls (Ravel et al. 2006; Christensen et al. 2008; Shi et al. 2011), and the functional impact of missense variants on enzyme activity appears to be low (Zhang et al. 2015; Liu et al. 2018). In vivo analysis of knock-out mice suggests that Usp26 is dispensable for mouse gametogenesis (Felipe-Medina et al. 2019). Hence, convincing evidence for an association of USP26 variants with male infertility is currently lacking.

\section{RHOX}

RHOX genes belong to a large multicopy homeobox gene cluster (Maclean et al. 2005) and are expressed in male germ cells (Song et al. 2013). In severe oligozoospermic patients, variants were described in the genes RHOXF 1 and RHOXF2 (Borgmann et al. 2016). However, it remains unclear whether variants in a single $R H O X$ gene could be causative for NOA, as other members of this large gene cluster might have redundant roles (MacLean and Wilkinson 2010). Further exploration of these ampliconic regions is necessary for a conclusive evaluation of pathogenicity.

\section{TAF7L}

The transcription factor $T A F 7 L$ is expressed during meiosis with a dynamically regulated intracellular localization (Pointud et al. 2003). Although Taf7l knock-out mice normally complete meiosis, they show reduced sperm production and abnormal sperm morphology (Cheng et al. 2007). Variants in $T A F 7 L$ were described as risk factors for spermatogenic failure (Akinloye et al. 2007), although most variants were also found in fertile controls (Stouffs et al. 2006). Taken together, the disease association of $T A F 7 L$ variants with azoospermia remains with no evidence.

\section{Obstructive azoospermia}

\section{ADGRG2}

Obstructive azoospermia can be caused by congenital bilateral absence of the vas deferens (CBAVD). In most CBAVD cases, recessive mutations are identified in the cystic fibrosis transmembrane conductance regulator gene (CFTR), and CFTR analysis by sequencing and screening for large rearrangements allows for a mutation detection rate of about $87 \%$ in CBAVD patients (Ratbi et al. 2007). By exome sequencing of CFTR-negative CBAVD patients, LoF mutations were recently identified in the X-linked ADGRG2 gene (Patat et al. 2016), which encodes an adhesion $\mathrm{G}$ protein-coupled receptor that is specifically expressed in the epididymis and efferent ducts 
(Obermann et al. 2003). Subsequently, further truncating and missense variants in ADGRG2 have been described (Yang et al. 2017; Yuan et al. 2019; Pagin et al. 2019). In accordance with human data, previous studies have already demonstrated that Adgrg2-knock-out male mice develop obstructive infertility (Davies et al. 2004). These studies established $A D G R G 2$ as a novel gene responsible for a specific subtype of obstructive azoospermia. The molecular mechanism of X-linked CBAVD remains uncertain, although a regulation of fluid reabsorption by G-proteindependent CFTR coupling and $\beta$-arrestin-dependent receptor internalization has been postulated (Zhang et al. 2018; Azimzadeh et al. 2019).

\section{CLDN2}

Recently, a $C L D N 2$ missense variant was described in a family with several male relatives affected by obstructive azoospermia (Askari et al. 2019). The encoded protein Claudin-2 is a paracellular transmembrane protein, and the authors proposed a gain-of-function effect on the blood-epididymis barrier by the missense variant. However, Cldn2-knock-out mice are fertile, and CLDN2 was shown to be expressed in leaky epithelia, in contrast to barrier-forming claudins like CLDN1/4 (Muto et al. 2010). It remains to be shown whether $C L D N 2$ variants can be responsible for obstructive azoospermia, e.g., by influencing the paracellular water transport in the epididymis.

\section{Teratozoospermia and asthenozoospermia}

\section{PIH1D3}

PIHID3 (also known as CXorf41) encodes a protein which plays a role in preassembly of both outer (ODA) and inner (IDA) dynein arms of cilia and sperm flagella (Dong et al. 2014; Paff et al. 2017; Olcese et al. 2017). Point mutations and complete PIHID3 gene deletions have been reported in patients affected by primary ciliary dyskinesia (PCD) (Paff et al. 2017; Olcese et al. 2017). PCD is a multisystemic disorder characterized by chronic respiratory tract infections, abnormally positioned internal organs and asthenozoospermia due to motility defects of cilia and flagella (Knowles et al. 2016). PCD can be caused by a number of genes, and transmission can be autosomal dominant, recessive or X-linked, with PIHID3 as the only validated X-linked PCD gene. For PIH1D3 carriers, ICSI is an option. However, it should be noted that they are at risk for transmission of the entire spectrum of symptoms to the female offspring in case their partner is a heterozygous carrier.

\section{AKAP4}

AKAP4 encodes a major structural component of sperm fibrous sheath (Turner et al. 1998). Intragenic deletions of the $A K A P 3$ and $A K A P 4$ genes were first described in a patient with total sperm immotility due to dysplasia of the fibrous sheath (DFS) (Baccetti et al. 2005). In 2011, an additional patient with DFS was reported carrying a hemizygous missense variant in AKAP4 (Visser et al. 2011). The Akap4defficient mice resemble the asthenozoospermic phenotype (Fang et al. 2019) observed in men. However, apart from these two case reports, AKAP4 mutations were not found in other cohorts of DFS patients, indicating currently limited evidence for this gene defect (Turner et al. 2001a, b; Yang et al. 2015b; Pereira et al. 2015).

\section{FATE1}

FATE1 belongs to the CTA family, and in 2003 it was sequenced in a cohort of 144 randomly selected infertile patients (Olesen et al. 2003). The authors reported two missense variants in two unrelated asthenozoospermic men. However, for one of the carriers a family study revealed that the variant was compatible with fertility; for the other one, the current bioinformatic tools predict the variant as benign. Therefore, given that no more cases have been reported since 2003 , it is highly unlikely that this gene plays an important role in male infertility.

\section{Hypogonadotropic hypogonadism}

\section{ANOS1}

ANOS1 (Xp22.31), previously called $K A L 1$, encodes the anosmin-1 glycoprotein which is involved in the migration of GnRH neurons. ANOS1 point mutations and gene deletions are the most common cause of Kallmann syndrome, a rare endocrine disease characterized by both congenital hypogonadotropic hypogonadism (cHH) and hyposmia/anosmia. ANOS1 mutations and deletions may explain the phenotype in about $5-10 \%$ of cases (Balasubramanian and Crowley 1993); in addition to ANOS1, mutations in more than 20 autosomal genes can also lead to Kallmann syndrome.

The reproductive phenotype of patients affected by $\mathrm{cHH}$ may range from the complete form with absent puberty (usually associated with cryptorchidism, micropenis and gynecomastia) to late-onset HH (Krausz et al. 2018 and references therein). Other non-reproductive and non-olfactory alterations described in $K A L 1$ mutation carriers are 
bimanual synkinesia (in about $80 \%$ of cases), unilateral renal dysgenesis (30\%), arched palate, tooth agenesis, hearing impairment, pes cavus and ptosis, among others (Balasubramanian and Crowley 1993; Dode and Hardelin 2009). Spermatogenesis is inducible with the administration of gonadotrophins, hence $\mathrm{cHH}$ patients may generate their own biological children either through natural conception or assisted reproductive techniques. Preimplantation genetic testing in syndromic forms is advisable to prevent the transmission of the mutation.

\section{Conclusions}

Currently, validated X chromosome-linked monogenic causes of male infertility are surprisingly rare. From a total of eight genes studied in men with idiopathic oligo/ azoospermia, only $A R$ and TEXI1 reach sufficiently high clinical evidence for inclusion in diagnostic testing. On the other hand, targeted studies on highly specific infertile phenotypes have successfully identified a novel gene for congenital absence of vas deferens (ADGRG2) and for complete asthenozoospermia due to primary ciliary dyskinesia (PIH1D3).

Although the $\mathrm{X}$ chromosome contains several structural elements which may predispose it to AZF-like deletions, only one deletion, CNV67, has been the object of multiple validation studies. This deletion affects MAGEA9, an ampliconic gene belonging to one of the CTA gene families. Similar to CNV67, the majority of X-linked deletions and duplications affect or remove CTA genes. These genes were independently acquired on the human $\mathrm{X}$ chromosome and are exclusively expressed in the testis in physiological conditions. Based on their expression profile and their predicted involvement in cell proliferation (expression in various cancers), these genes are predicted to play a role in spermatogenesis. However, the interpretation of mutations in CTA genes is largely limited by their multicopy nature (implying possible compensation by the retained copies) and the lack of model animals (due to their exclusive presence in the human genome). Future, targeted studies are warranted on this specific group of peculiar genes.

The paucity of clinically relevant $\mathrm{X}$-linked anomalies in oligo/azoospermia is in sharp contrast with the predicted specialization of this chromosome in male reproductive fitness. Reasons for these disappointing results can be related to the fact that the majority of studies focusing on quantitative impairment of spermatogenesis were based on Sanger re-sequencing of a few candidate genes. Ongoing exome analyses or whole $\mathrm{X}$ chromosome gene panel studies in large patient cohorts are likely to reveal novel X-linked genetic factors in the near future. A major challenge for the ongoing studies based on massive parallel sequencing remains the discovery and the demonstration of the pathogenic effect of mutations in multicopy spermatogenesis candidate genes.

Acknowledgements This work was in part supported by the Spanish Ministry of Health Instituto Carlos III-FIS (Grant number: FIS/ FEDER-PI14/01250; PI17/01822), the European Commission, Reproductive Biology Early Research Training (REPROTRAIN, project number: 289880) (both awarded to CK and AR-E), the Fondazione Ente Cassa di Risparmio di Firenze (Grant to CK), and the German Research Foundation Clinical Research Unit 'Male Germ Cells: from Genes to Function' (DFG CRU326, Grants to FT). The authors thank Celeste Brennecka for editorial assistance.

\section{Compliance with ethical standards}

Conflict of interest The authors declare that they have no conflicts of interest.

Open Access This article is licensed under a Creative Commons Attribution 4.0 International License, which permits use, sharing, adaptation, distribution and reproduction in any medium or format, as long as you give appropriate credit to the original author(s) and the source, provide a link to the Creative Commons licence, and indicate if changes were made. The images or other third party material in this article are included in the article's Creative Commons licence, unless indicated otherwise in a credit line to the material. If material is not included in the article's Creative Commons licence and your intended use is not permitted by statutory regulation or exceeds the permitted use, you will need to obtain permission directly from the copyright holder. To view a copy of this licence, visit http://creativecommons.org/licenses/by/4.0/.

\section{References}

Adelman CA, Petrini JHJ (2008) ZIP4H (TEX11) deficiency in the mouse impairs meiotic double strand break repair and the regulation of crossing over. PLoS Genet 4:e1000042. https://doi. org/10.1371/journal.pgen.1000042

Akinloye O, Gromoll J, Callies C et al (2007) Mutation analysis of the X-chromosome linked, testis-specific TAF7L gene in spermatogenic failure. Andrologia 39:190-195. https://doi.org/10.1 111/j.1439-0272.2007.00789.x

Almeida LG, Sakabe NJ, DeOliveira AR et al (2009) CTdatabase: a knowledge-base of high-throughput and curated data on cancertestis antigens. Nucleic Acids Res 37:D816-D819. https://doi. org/10.1093/nar/gkn673

Askari M, Karamzadeh R, Ansari-Pour N et al (2019) Identification of a missense variant in CLDN2 in obstructive azoospermia. J Hum Genet 64:1023-1032. https://doi.org/10.1038/s 1003 8-019-0642-0

Azimzadeh P, Talamantez-Lyburn SC, Chang KT et al (2019) Spatial regulation of GPR64/ADGRG2 signaling by $\beta$-arrestins and GPCR kinases. Ann NY Acad Sci 1456:26-43. https://doi. org/10.1111/nyas. 14227

Baccetti B, Collodel G, Estenoz M et al (2005) Gene deletions in an infertile man with sperm fibrous sheath dysplasia. Hum Reprod 20:2790-2794. https://doi.org/10.1093/humrep/dei126

Balasubramanian R, Crowley WF (1993) Isolated gonadotropin-releasing hormone (GnRH) deficiency. In: Adam MP, Ardinger HH, Pagon RA et al (eds) GeneReviews. Seattle. https://www.ncbi. nlm.nih.gov/books/NBK1334/ 
Bellott DW, Skaletsky H, Pyntikova T et al (2010) Convergent evolution of chicken $\mathrm{Z}$ and human $\mathrm{X}$ chromosomes by expansion and gene acquisition. Nature 466:612-616. https://doi.org/10.1038/ nature 09172

Bojesen A, Hertz JM, Gravholt CH (2011) Genotype and phenotype in Klinefelter syndrome-impact of androgen receptor polymorphism and skewed $\mathrm{X}$ inactivation. Int $\mathrm{J}$ Androl 34:e642-e648. https://doi.org/10.1111/j.1365-2605.2011.01223.X

Borgmann J, Tüttelmann F, Dworniczak B et al (2016) The human RHOX gene cluster: target genes and functional analysis of gene variants in infertile men. Hum Mol Genet 25:4898-4910. https:// doi.org/10.1093/hmg/ddw313

Brinkmann AO (2001) Molecular basis of androgen insensitivity. Mol Cell Endocrinol 179:105-109. https://doi.org/10.1016/S0303 -7207(01)00466-X

Bruining H, van Rijn S, Swaab H et al (2010) The parent-of-origin of the extra $\mathrm{X}$ chromosome may differentially affect psychopathology in Klinefelter syndrome. Biol Psychiatry 68:1156-1162. https://doi.org/10.1016/j.biopsych.2010.08.034

Chang S, Skakkebaek A, Trolle C et al (2015) Anthropometry in Klinefelter syndrome-multifactorial influences due to CAG length, testosterone treatment and possibly intrauterine hypogonadism. $\mathrm{J}$ Clin Endocrinol Metab 100:E508-E517. https://doi.org/10.1210/ jc.2014-2834

Cheng Y, Buffone MG, Kouadio M et al (2007) Abnormal sperm in mice lacking the Taf7l gene. Mol Cell Biol 27:2582-2589. https ://doi.org/10.1128/MCB.01722-06

Christensen GL, Griffin J, Carrell DT (2008) Sequence analysis of the X-linked USP26 gene in severe male factor infertility patients and fertile controls. Fertil Steril 90:851-852. https:// doi.org/10.1016/j.fertnstert.2007.06.096

Corona G, Pizzocaro A, Lanfranco F et al (2017) Sperm recovery and ICSI outcomes in Klinefelter syndrome: a systematic review and meta-analysis. Hum Reprod Update. https://doi.org/10.1093/ humupd/dmx008

Cortes CJ, La Spada AR (2018) X-linked spinal and bulbar muscular atrophy: from clinical genetic features and molecular pathology to mechanisms underlying disease toxicity. Adv Exp Med Biol 1049:103-133. https://doi.org/10.1007/978-3-319-71779-1_5

Davies B, Baumann C, Kirchhoff C et al (2004) Targeted deletion of the epididymal receptor HE6 results in fluid dysregulation and male infertility. Mol Cell Biol 24:8642-8648. https://doi.org/10.1128/ MCB.24.19.8642-8648.2004

Davis-Dao CA, Tuazon ED, Sokol RZ, Cortessis VK (2007) Male infertility and variation in CAG repeat length in the androgen receptor gene: a meta-analysis. J Clin Endocrinol Metab 92:4319-4326. https://doi.org/10.1210/jc.2007-1110

Deng X, Berletch JB, Nguyen DK, Disteche CM (2014) X chromosome regulation: diverse patterns in development, tissues and disease. Nat Rev Genet 15:367-378. https://doi.org/10.1038/nrg3687

Dode C, Hardelin J-P (2009) Kallmann syndrome. Eur J Hum Genet 17:139-146. https://doi.org/10.1038/ejhg.2008.206

Dong F, Shinohara K, Botilde Y et al (2014) Pih1d3 is required for cytoplasmic preassembly of axonemal dynein in mouse sperm. $\mathrm{J}$ Cell Biol 204:203-213. https://doi.org/10.1083/jcb.201304076

Eisenberg ML, Li S, Behr B et al (2014) Semen quality, infertility and mortality in the USA. Hum Reprod 29:1567-1574. https://doi. org/10.1093/humrep/deu106

Fang X, Huang L-L, Xu J et al (2019) Proteomics and single-cell RNA analysis of Akap4-knockout mice model confirm indispensable role of Akap4 in spermatogenesis. Dev Biol 454:118-127. https ://doi.org/10.1016/j.ydbio.2019.06.017

Felipe-Medina N, Gómez-H L, Condezo YB et al (2019) Ubiquitinspecific protease 26 (USP26) is not essential for mouse gametogenesis and fertility. Chromosoma. https://doi.org/10.1007/ s00412-019-00697-6
Ferlin A, Bartoloni L, Rizzo G et al (2004) Androgen receptor gene CAG and GGC repeat lengths in idiopathic male infertility. Mol Hum Reprod 10:417-421. https://doi.org/10.1093/molehr/gah05 4

Ferlin A, Vinanzi C, Garolla A et al (2006) Male infertility and androgen receptor gene mutations: clinical features and identification of seven novel mutations. Clin Endocrinol (Oxf) 65:606-610. https://doi.org/10.1111/j.1365-2265.2006.02635.x

Feuk L, Carson AR, Scherer SW (2006) Structural variation in the human genome. Nat Rev Genet 7:85-97. https://doi.org/10.1038/ $\operatorname{nrg} 1767$

Fratta E, Coral S, Covre A et al (2011) The biology of cancer testis antigens: putative function, regulation and therapeutic potential. Mol Oncol 5:164-182. https://doi.org/10.1016/j.molon c. 2011.02 .001

Gao T, Marcelli M, McPhaul MJ (1996) Transcriptional activation and transient expression of the human androgen receptor. J Steroid Biochem Mol Biol 59:9-20

Goglia U, Vinanzi C, Zuccarello D et al (2011) Identification of a novel mutation in exon 1 of androgen receptor gene in an azoospermic patient with mild androgen insensitivity syndrome: case report and literature review. Fertil Steril 96:1165-1169. https://doi. org/10.1016/j.fertnstert.2011.08.033

Gonçalves CI, Fonseca F, Borges T et al (2017) Expanding the genetic spectrum of ANOS1 mutations in patients with congenital hypogonadotropic hypogonadism. Hum Reprod 32:704-711. https:// doi.org/10.1093/humrep/dew354

Goshima G, Mayer M, Zhang N et al (2008) Augmin: a protein complex required for centrosome-independent microtubule generation within the spindle. J Cell Biol 181:421-429. https://doi. org/10.1083/jcb.200711053

Gottlieb B, Beitel LK, Nadarajah A et al (2012) The androgen receptor gene mutations database: 2012 update. Hum Mutat 33:887894. https://doi.org/10.1002/humu.22046

Gravholt CH, Chang S, Wallentin M et al (2018) Klinefelter Syndrome: integrating genetics, neuropsychology, and endocrinology. Endocr Rev 39:389-423. https://doi.org/10.1210/ er.2017-00212

Grigorova M, Punab M, Kahre T et al (2017) The number of CAG and GGN triplet repeats in the Androgen Receptor gene exert combinatorial effect on hormonal and sperm parameters in young men. Andrology 5:495-504. https://doi.org/10.1111/andr.12344

Gurbich TA, Bachtrog D (2008) Gene content evolution on the X chromosome. Curr Opin Genet Dev 18:493-498. https://doi. org/10.1016/j.gde.2008.09.006

Hiort O, Holterhus PM, Horter T et al (2000) Significance of mutations in the androgen receptor gene in males with idiopathic infertility. J Clin Endocrinol Metab 85:2810-2815. https://doi.org/10.1210/ jcem.85.8.6713

Hurles ME, Dermitzakis ET, Tyler-Smith C (2008) The functional impact of structural variation in humans. Trends Genet 24:238245. https://doi.org/10.1016/j.tig.2008.03.001

Jääskeläinen J (2012) Molecular biology of androgen insensitivity. Mol Cell Endocrinol 352:4-12. https://doi.org/10.1016/j. mce.2011.08.006

Jacobs PA, Strong JA (1959) A case of human intersexuality having a possible XXY sex-determining mechanism. Nature 183:302-303. https://doi.org/10.1038/183302a0

Jensen TK, Jacobsen R, Christensen K et al (2009) Good semen quality and life expectancy: a cohort study of 43,277 men. Am J Epidemiol 170:559-565. https://doi.org/10.1093/aje/kwp168

Khil PP, Smirnova NA, Romanienko PJ, Camerini-Otero RD (2004) The mouse $\mathrm{X}$ chromosome is enriched for sex-biased genes not subject to selection by meiotic sex chromosome inactivation. Nat Genet 36:642-646. https://doi.org/10.1038/ng1368 
Klinefelter HF, Reifenstein EC, Albright F (1942) Syndrome characterized by gynecomastia, aspermatogenesis without A-Leydigism, and increased excretion of follicle-stimulating hormone. J Clin Endocrinol Metab 2:615-627. https://doi.org/10.1210/ jcem-2-11-615

Knowles MR, Zariwala M, Leigh M (2016) Primary Ciliary Dyskinesia. Clin Chest Med 37:449-461. https://doi.org/10.1016/j. ccm.2016.04.008

Krausz C, Casamonti E (2017) Spermatogenic failure and the Y chromosome. Hum Genet 136:637-655. https://doi.org/10.1007/ s00439-017-1793-8

Krausz C, Riera-Escamilla A (2018) Genetics of male infertility. Nat Rev Urol. https://doi.org/10.1038/s41585-018-0003-3

Krausz C, Giachini C, Lo Giacco D et al (2012) High resolution X chromosome-specific array-CGH detects new CNVs in infertile males. PLoS ONE 7:e44887. https://doi.org/10.1371/journ al.pone. 0044887

Krausz C, Hoefsloot L, Simoni M et al (2014) EAA/EMQN best practice guidelines for molecular diagnosis of Y-chromosomal microdeletions: state-of-the-art 2013. Andrology 2:5-19. https://doi. org/10.1111/j.2047-2927.2013.00173.x

Krausz C, Escamilla AR, Chianese C (2015) Genetics of male infertility: from research to clinic. Reproduction 150:R159-R174

Krausz C, Cioppi F, Riera-Escamilla A (2018) Testing for genetic contributions to infertility: potential clinical impact. Expert Rev Mol Diagn 18:331-346. https://doi.org/10.1080/14737 159.2018.1453358

Kruger AN, Ellison Q, Brogley MA et al (2018) Male mice with large inversions or deletions of X-chromosome palindrome arms are fertile and express their associated genes during post-meiosis. Sci Rep 8:8985. https://doi.org/10.1038/s41598-018-27360-x

Kuroiwa A, Tsuchiya K, Watanabe T et al (2001) Conservation of the rat $\mathrm{X}$ chromosome gene order in rodent species. Chromosome Res 9:61-67

Larson EL, Kopania EEK, Good JM (2018) Spermatogenesis and the evolution of mammalian sex chromosomes. Trends Genet 34:722-732. https://doi.org/10.1016/j.tig.2018.06.003

Lee AK, Potts PR (2017) A Comprehensive Guide to the MAGE Family of Ubiquitin Ligases. J Mol Biol 429:1114-1142. https://doi. org/10.1016/j.jmb.2017.03.005

Li L, Sha Y-W, Su Z-Y et al (2018) A novel mutation in HAUS7 results in severe oligozoospermia in two brothers. Gene 639:106-110. https://doi.org/10.1016/j.gene.2017.10.014

Liu Y-L, Zheng J, Mi Y-J et al (2018) The impacts of nineteen mutations on the enzymatic activity of USP26. Gene 641:292-296. https://doi.org/10.1016/j.gene.2017.10.074

Lo Giacco D, Chianese C, Ars E et al (2014) Recurrent X chromosomelinked deletions: discovery of new genetic factors in male infertility. J Med Genet 51:340-344. https://doi.org/10.1136/jmedg enet-2013-101988

Lopes AM, Aston KI, Thompson E et al (2013) Human spermatogenic failure purges deleterious mutation load from the autosomes and both sex chromosomes, including the gene DMRT1. PLoS Genet 9:e1003349. https://doi.org/10.1371/journal.pgen.1003349

Luddi A, Crifasi L, Quagliarello A et al (2016) Single nucleotide polymorphisms of USP26 in azoospermic men. Syst Biol Reprod Med 62:372-378. https://doi.org/10.1080/19396368.2016.12381 16

Ma Q, Li Y, Guo H et al (2016) A novel missense mutation in USP26 gene is associated with nonobstructive azoospermia. Reprod Sci 23:1434-1441. https://doi.org/10.1177/1933719116641758

Ma X, Kuete M, Gu X et al (2017) Recurrent deletions of the X chromosome linked CNV64, CNV67, and CNV69 shows geographic differences across China and no association with idiopathic infertility in men. PLoS One 12:e0185084. https:// doi.org/10.1371/journal.pone.0185084

MacLean JA, Wilkinson MF (2010) The Rhox genes. Reproduction 140:195-213. https://doi.org/10.1530/REP-10-0100

Maclean JA, Chen MA, Wayne CM et al (2005) Rhox: a new homeobox gene cluster. Cell 120:369-382. https://doi.org/10.1016/j. cell.2004.12.022

McCrea E, Sissung TM, Price DK et al (2016) Androgen receptor variation affects prostate cancer progression and drug resistance. Pharmacol Res 114:152-162. https://doi.org/10.1016/j. phrs.2016.10.001

Mueller JL, Mahadevaiah SK, Park PJ et al (2008) The mouse X chromosome is enriched for multicopy testis genes showing postmeiotic expression. Nat Genet 40:794-799. https://doi.org/10.1038/ ng. 126

Mueller JL, Skaletsky H, Brown LG et al (2013) Independent specialization of the human and mouse $\mathrm{X}$ chromosomes for the male germ line. Nat Genet 45:1083-1087. https://doi.org/10.1038/ ng. 2705

Murphy WJ, Sun S, Chen ZQ et al (1999) Extensive conservation of sex chromosome organization between cat and human revealed by parallel radiation hybrid mapping. Genome Res 9:1223-1230. https://doi.org/10.1101/gr.9.12.1223

Muto S, Hata M, Taniguchi J et al (2010) Claudin-2-deficient mice are defective in the leaky and cation-selective paracellular permeability properties of renal proximal tubules. Proc Natl Acad Sci USA 107:8011-8016. https://doi.org/10.1073/pnas.0912901107

Naqvi S, Godfrey AK, Hughes JF et al (2019) Conservation, acquisition, and functional impact of sex-biased gene expression in mammals. Science. https://doi.org/10.1126/science.aaw7317

O'Hara L, Smith LB (2015) Androgen receptor roles in spermatogenesis and infertility. Best Pract Res Clin Endocrinol Metab 29:595-605. https://doi.org/10.1016/j.beem.2015.04.006

Obermann H, Samalecos A, Osterhoff C et al (2003) HE6, a two-subunit heptahelical receptor associated with apical membranes of efferent and epididymal duct epithelia. Mol Reprod Dev 64:1326. https://doi.org/10.1002/mrd.10220

Ohno S (1967) Sex chromosomes and sex-linked genes. Springer Berlin Heidelberg, Berlin

Okutman O, Muller J, Skory V et al (2017) A no-stop mutation in MAGEB4 is a possible cause of rare X-linked azoospermia and oligozoospermia in a consanguineous Turkish family. J Assist Reprod Genet 34:683-694. https://doi.org/10.1007/s1081 5-017-0900-z

Olcese C, Patel MP, Shoemark A et al (2017) X-linked primary ciliary dyskinesia due to mutations in the cytoplasmic axonemal dynein assembly factor PIH1D3. Nat Commun 8:14279. https:// doi.org/10.1038/ncomms14279

Olesen C, Silber J, Eiberg H et al (2003) Mutational analysis of the human FATE gene in 144 infertile men. Hum Genet 113:195201. https://doi.org/10.1007/s00439-003-0974-9

Osterlund C, Töhönen V, Forslund KO, Nordqvist K (2000) Mage-b4, a novel melanoma antigen (MAGE) gene specifically expressed during germ cell differentiation. Cancer Res 60:1054-1061

Ottesen AM, Aksglaede L, Garn I et al (2010) Increased number of sex chromosomes affects height in a nonlinear fashion: a study of 305 patients with sex chromosome aneuploidy. Am J Med Genet A 152A:1206-1212. https://doi.org/10.1002/ajmg.a.33334

Oud MS, Volozonoka L, Smits RM et al (2019) A systematic review and standardized clinical validity assessment of male infertility genes. Hum Reprod 34:932-941. https://doi.org/10.1093/humre $\mathrm{p} / \mathrm{dez} 022$

Paduch DA, Mielnik A, Schlegel PN (2005) Novel mutations in testisspecific ubiquitin protease 26 gene may cause male infertility and hypogonadism. Reprod Biomed Online 10:747-754 
Paff T, Loges NT, Aprea I et al (2017) Mutations in PIH1D3 cause $\mathrm{X}$-linked primary ciliary dyskinesia with outer and inner dynein arm defects. Am J Hum Genet 100:160-168. https://doi. org/10.1016/j.ajhg.2016.11.019

Pagin A, Bergougnoux A, Girodon E et al (2019) Novel ADGRG2 truncating variants in patients with $\mathrm{X}$-linked Congenital Absence of Vas Deferens. Andrology. https://doi.org/10.1111/andr.12744

Parsch J, Ellegren H (2013) The evolutionary causes and consequences of sex-biased gene expression. Nat Rev Genet 14:83-87. https:// doi.org/10.1038/nrg3376

Patat O, Pagin A, Siegfried A et al (2016) Truncating mutations in the adhesion $\mathrm{G}$ protein-coupled receptor $\mathrm{G} 2$ gene $A D G R G 2$ cause an $\mathrm{X}$-linked congenital bilateral absence of vas deferens. Am J Hum Genet 99:437-442. https://doi.org/10.1016/j.ajhg.2016.06.012

Pereira R, Oliveira J, Ferraz L et al (2015) Mutation analysis in patients with total sperm immotility. J Assist Reprod Genet 32:893-902. https://doi.org/10.1007/s10815-015-0474-6

Pinho A, Barros A, Fernandes S (2019) Clinical and molecular characterization of Y microdeletions and X-linked CNV67 implications in male fertility: a 20-year experience. Andrology. https://doi. org/10.1111/andr.12686

Pointud J-C, Mengus G, Brancorsini S et al (2003) The intracellular localisation of TAF7L, a paralogue of transcription factor TFIID subunit TAF7, is developmentally regulated during male germ-cell differentiation. J Cell Sci 116:1847-1858. https://doi. org/10.1242/jcs.00391

Ratbi I, Legendre M, Niel F et al (2007) Detection of cystic fibrosis transmembrane conductance regulator (CFTR) gene rearrangements enriches the mutation spectrum in congenital bilateral absence of the vas deferens and impacts on genetic counselling. Hum Reprod 22:1285-1291. https://doi.org/10.1093/humrep/ dem024

Raudsepp T, Lee E-J, Kata SR et al (2004) Exceptional conservation of horse-human gene order on X chromosome revealed by highresolution radiation hybrid mapping. Proc Natl Acad Sci USA 101:2386-2391. https://doi.org/10.1073/pnas.0308513100

Ravel C, El Houate B, Chantot S et al (2006) Haplotypes, mutations and male fertility: the story of the testis-specific ubiquitin protease USP26. Mol Hum Reprod 12:643-646. https://doi. org/10.1093/molehr/gal063

Rohayem J, Fricke R, Czeloth K et al (2015) Age and markers of Leydig cell function, but not of Sertoli cell function predict the success of sperm retrieval in adolescents and adults with Klinefelter's syndrome. Andrology 3:868-875. https://doi.org/10.1111/ andr.12067

Ross MT, Grafham DV, Coffey AJ et al (2005) The DNA sequence of the human X chromosome. Nature 434:325-337. https://doi. org/10.1038/nature03440

Salonia A, Matloob R, Gallina A et al (2009) Are infertile men less healthy than fertile men? Results of a prospective case-control survey. Eur Urol 56:1025-1031. https://doi.org/10.1016/j.eurur 0.2009 .03 .001

Sharma A, Jamil MA, Nuesgen N et al (2015) DNA methylation signature in peripheral blood reveals distinct characteristics of human $\mathrm{X}$ chromosome numerical aberrations. Clin Epigenetics 7:76. https://doi.org/10.1186/s13148-015-0112-2

Shen Y, Xu J, Yang X et al (2017) Evidence for the involvement of the proximal copy of the MAGEA9 gene in Xq28-linked CNV67 specific to spermatogenic failure. Biol Reprod 96:610-616. https ://doi.org/10.1093/biolre/iox006

Shi Y, Wei L, Cui Y et al (2011) Association between ubiquitin-specific protease USP26 polymorphism and male infertility in Chinese men. Clin Chim Acta 412:545-549. https://doi.org/10.1016/j. cca.2010.12.005
Simpson AJG, Caballero OL, Jungbluth A et al (2005) Cancer/testis antigens, gametogenesis and cancer. Nat Rev Cancer 5:615-625. https://doi.org/10.1038/nrc1669

Skakkebaek A, Nielsen MM, Trolle C et al (2018) DNA hypermethylation and differential gene expression associated with Klinefelter syndrome. Sci Rep 8:13740. https://doi.org/10.1038/ s41598-018-31780-0

Skaletsky H, Kuroda-Kawaguchi T, Minx PJ et al (2003) The malespecific region of the human $\mathrm{Y}$ chromosome is a mosaic of discrete sequence classes. Nature 423:825-837. https://doi. org/10.1038/nature01722

Smith ED, Radtke K, Rossi M et al (2017) Classification of Genes: standardized Clinical Validity Assessment of Gene-Disease Associations Aids Diagnostic Exome Analysis and Reclassifications. Hum Mutat 38:600-608. https://doi.org/10.1002/ humu. 23183

Song HW, Anderson RA, Bayne RA et al (2013) The RHOX homeobox gene cluster is selectively expressed in human oocytes and male germ cells. Hum Reprod 28:1635-1646. https://doi. org/10.1093/humrep/det043

Stemkens D, Roza T, Verrij L et al (2006) Is there an influence of X-chromosomal imprinting on the phenotype in Klinefelter syndrome? A clinical and molecular genetic study of 61 cases. Clin Genet 70:43-48. https://doi.org/10.111 1/j.1399-0004.2006.00635.x

Stouffs K, Willems A, Lissens W et al (2006) The role of the testisspecific gene hTAF7L in the aetiology of male infertility. Mol Hum Reprod 12:263-267. https://doi.org/10.1093/molehr/ gal020

Stouffs K, Vandermaelen D, Massart A et al (2012) Array comparative genomic hybridization in male infertility. Hum Reprod 27:921929. https://doi.org/10.1093/humrep/der440

Tartaglia N, Davis S, Hench A et al (2008) A new look at XXYY syndrome: medical and psychological features. Am J Med Genet A 146A:1509-1522. https://doi.org/10.1002/ajmg.a.32366

Tournaye H, Krausz C, Oates RD (2016) Novel concepts in the aetiology of male reproductive impairment. Lancet Diabetes Endocrinol 5:544-553. https://doi.org/10.1016/S2213-8587(16)30040 $-7$

Turner JMA (2007) Meiotic sex chromosome inactivation. Development 134:1823-1831. https://doi.org/10.1242/dev.000018

Turner RM, Johnson LR, Haig-Ladewig L et al (1998) An X-linked gene encodes a major human sperm fibrous sheath protein, hAKAP82. Genomic organization, protein kinase A-RII binding, and distribution of the precursor in the sperm tail. J Biol Chem 273:32135-32141. https://doi.org/10.1074/jbc.273.48.32135

Turner RM, Foster JA, Gerton GL et al (2001a) Molecular evaluation of two major human sperm fibrous sheath proteins, pro-hAKAP82 and hAKAP82, in stump tail sperm. Fertil Steril 76:267-274. https://doi.org/10.1016/s0015-0282(01)01922-7

Turner RM, Musse MP, Mandal A et al (2001b) Molecular genetic analysis of two human sperm fibrous sheath proteins, AKAP4 and AKAP3, in men with dysplasia of the fibrous sheath. $\mathbf{J}$ Androl 22:302-315

Tut TG, Ghadessy FJ, Trifiro MA et al (1997) Long polyglutamine tracts in the androgen receptor are associated with reduced transactivation, impaired sperm production, and male infertility. J Clin Endocrinol Metab 82:3777-3782. https://doi.org/10.1210/ jcem.82.11.4385

Tüttelmann F, Gromoll J (2010) Novel genetic aspects of Klinefelter's syndrome. Mol Hum Reprod 16:386-395. https://doi. org/10.1093/molehr/gaq019

Tüttelmann F, Simoni M, Kliesch S et al (2011) Copy number variants in patients with severe oligozoospermia and sertoli-cell-only syndrome. PLoS One 6:e19426. https://doi.org/10.1371/journ al.pone. 0019426 
Viana J, Pidsley R, Troakes C et al (2014) Epigenomic and transcriptomic signatures of a Klinefelter syndrome (47, XXY) karyotype in the brain. Epigenetics 9:587-599. https://doi.org/10.4161/ epi.27806

Vicoso B, Charlesworth B (2006) Evolution on the X chromosome: unusual patterns and processes. Nat Rev Genet 7:645-653. https ://doi.org/10.1038/nrg 1914

Visootsak J, Aylstock M, Graham JMJ (2001) Klinefelter syndrome and its variants: an update and review for the primary pediatrician. Clin Pediatr (Phila) 40:639-651. https://doi.org/10.1177/00099 2280104001201

Visser L, Westerveld GH, Xie F et al (2011) A comprehensive gene mutation screen in men with asthenozoospermia. Fertil Steril 95:1020-1029. https://doi.org/10.1016/j.fertnstert.2010.11.067

Vogt PH, Edelmann A, Kirsch S et al (1996) Human Y chromosome azoospermia factors (AZF) mapped to different subregions in Yq11. Hum Mol Genet 5:933-943

Wan ES, Qiu W, Morrow J et al (2015) Genome-wide site-specific differential methylation in the blood of individuals with Klinefelter syndrome. Mol Reprod Dev 82:377-386. https://doi.org/10.1002/ $\operatorname{mrd} .22483$

Wang PJ, McCarrey JR, Yang F, Page DC (2001) An abundance of X-linked genes expressed in spermatogonia. Nat Genet 27:422426. https://doi.org/10.1038/86927

Warburton PE, Giordano J, Cheung F et al (2004) Inverted repeat structure of the human genome: the X-chromosome contains a preponderance of large, highly homologous inverted repeats that contain testes genes. Genome Res 14:1861-1869. https:// doi.org/10.1101/gr.2542904

Wikstrom AM, Painter JN, Raivio T et al (2006) Genetic features of the X chromosome affect pubertal development and testicular degeneration in adolescent boys with Klinefelter syndrome. Clin Endocrinol (Oxf) 65:92-97. https://doi.org/10.111 $1 / \mathrm{j} .1365-2265.2006 .02554 . x$

Xiao F, Lan A, Lin Z et al (2016) Impact of CAG repeat length in the androgen receptor gene on male infertility - a meta-analysis. Reprod Biomed Online 33:39-49. https://doi.org/10.1016/j. rbmo.2016.03.012

Yang F, Gell K, van der Heijden GW et al (2008) Meiotic failure in male mice lacking an X-linked factor. Genes Dev 22:682-691. https://doi.org/10.1101/gad.1613608

Yang F, Silber S, Leu NA et al (2015a) TEX11 is mutated in infertile men with azoospermia and regulates genome-wide recombination rates in mouse. EMBO Mol Med 7:1198-1210. https://doi. org/10.15252/emmm.201404967
Yang S-M, Li H-B, Wang J-X et al (2015b) Morphological characteristics and initial genetic study of multiple morphological anomalies of the flagella in China. Asian J Androl 17:513-515

Yang B, Wang J, Zhang W et al (2017) Pathogenic role of ADGRG2 in CBAVD patients replicated in Chinese population. Andrology 5:954-957. https://doi.org/10.1111/andr.12407

Yatsenko AN, Georgiadis AP, Röpke A et al (2015) X-linked TEX11 mutations, meiotic arrest, and azoospermia in infertile men. $\mathrm{N}$ Engl J Med 372:2097-2107. https://doi.org/10.1056/NEJMo a1406192

Yuan P, Liang ZK, Liang H et al (2019) Expanding the phenotypic and genetic spectrum of Chinese patients with congenital absence of vas deferens bearing CFTR and ADGRG2 alleles. Andrology 7:329-340. https://doi.org/10.1111/andr.12592

Zendman AJW, Ruiter DJ, Van Muijen GNP (2003) Cancer/testisassociated genes: identification, expression profile, and putative function. J Cell Physiol 194:272-288. https://doi.org/10.1002/ jcp. 10215

Zhang W, Liu T, Mi Y-J et al (2015) Evidence from enzymatic and meta-analyses does not support a direct association between USP26 gene variants and male infertility. Andrology 3:271-279. https://doi.org/10.1111/andr.295

Zhang D-L, Sun Y-J, Ma M-L et al (2018) Gq activity- and $\beta$-arrestin-1 scaffolding-mediated ADGRG2/CFTR coupling are required for male fertility. Elife 7:e33432. https://doi.org/10.7554/eLife .33432

Zitzmann M, Depenbusch M, Gromoll J, Nieschlag E (2004) X-chromosome inactivation patterns and androgen receptor functionality influence phenotype and social characteristics as well as pharmacogenetics of testosterone therapy in Klinefelter patients. J Clin Endocrinol Metab 89:6208-6217. https://doi.org/10.1210/ jc. 2004-1424

Zitzmann M, Bongers R, Werler S et al (2015) Gene expression patterns in relation to the clinical phenotype in Klinefelter syndrome. J Clin Endocrinol Metab 100:E518-E523. https://doi. org/10.1210/jc.2014-2780

Publisher's Note Springer Nature remains neutral with regard to jurisdictional claims in published maps and institutional affiliations. 